Journal of Business Management and
Economic Research

\title{
The Academic Curriculum in The Humanisation of Business Teaching: The Perception of University Professors
}

\author{
Orlando Petiz Pereira \\ University of Minho / Economics \& Management School /Portugal \\ orlandop@eeg.uminho.pt \\ ORCID ID: http://orcid.org/0000-0003-4635-2696 \\ (Correspondence author)
}

\section{Carlos Arriaga Costa}

University of Minho / Economics \& Management School /Portugal caac@eeg.uminho.pt

ORCID ID: http://orcid.org/0000-0002-6786-3578

\begin{abstract}
Purpose: underline the advantages of reconciling the objectives of teaching of economics and business sciences with the objectives of companies while observing their social responsibility.

Design/methodology/approach: the study uses the Focus Group methodology with content analysis. The study addressed a Portuguese public university.

Findings: The study highlights the disparity between university practices, still very focused on the results of academic research, and the requirements that companies expect from universities.

Research limitations/implications: the study should include more universities and courses. It should implement a reflection by themes and focus group focus through the dynamics of a methodology under discussion.

Practical implications: the study provides guidance to humanise business-oriented education through curricular innovation.

Social implications: the business teaching model should transcend a set of disciplines focused on technical and instrumental training because this sort of orientation dehumanises social relations.

Originality/value: the theme sensitises citizens and institutions to other ways of being, teaching and learning with a view to improve the performance of the companies and businesses and nurture more social well-being and every citizen's daily life.
\end{abstract}

Keywords: Education, business, humanisation, values, school curriculum.

JEL Codes: I 23; I 29; I 31; M 29

\section{Suggested Citation:}

Pereira, O. P \& Costa, C. A. (2020). The Academic Curriculum in The Humanisation of Business Teaching: The Perception of University Professors. Journal of Business Management and Economic Research (JOBMER), Vol: 4, Issue: 2, 199-215 


\section{Introduction}

It is interesting to start with the notion that business training demand has grown dramatically (Ireland, 2015). In order to respond to this demand, and in order to meet the needs of an increasingly demanding labour market, both universities and polytechnic institutes have implemented business courses at various levels of undergraduate and specialisation programmes. Simultaneously, and in line with a more complex and competitive academic market, business schools have been pressured to publish their scientific research in indexed international journals, which has been considered as the route to greater visibility and reputation of their mission. This situation has led business schools to guide their efforts to publish the research with high ranking concerns and they seem to care much less on finding novel consistent responses to the actual needs of companies. On the other hand, this strategy has not been accompanied by the dissemination of research results within the companies or by the dissemination of information on students' performance in the classroom, nor on the search for new curricula more socially responsible (DeNisi and Pettigrew, 2012). This situation does not happen only in schools that are more business-oriented, but also in all scientific areas, associating the excellence of the university with competitive research, even if such practice implies some sacrifice of the pedagogical performance, which sometimes may neglect the importance of the student awareness and social attitude in the teaching of business.

Although schools are the largest social organisation of contemporary societies (Lai et al. 2015), students continue to be trained/educated to respond to demands from a market much more oriented toward competition rather than to social concerns. Such "training" and such a "competitive school" tend to care much less about the importance of the objectives of integrating training with the humanisation of society because such principles overlap and clash with the values of cooperation, tolerance, companionship, help and the values of sharing. Hence, the criticism that has arisen to business schools, in which it is emphasised that students should be prepared holistically and endowed with technical, instrumental, personal, cultural, relational and social skills to know how to respond to questions like "Who I am?", “What do I care about?", “What does success look like?", "What does it take to lead well?" (Khurana and Snook, 2011). This is exactly what is not actually being done.

This study addresses the business teaching model, considering, on the one hand, a teaching methodology that mirrors the results of research in the business area and, on the other hand, what are the companies' expectations in what concerns this sort of teaching. It is emphasised that the humanisation of business is the link between the various purposes, both of the university and of companies and society in general. 
As a methodology, the study is structured in two focus group. These were held at a Portuguese university and their actors are tenured professors in the area of economic and management sciences.

The work is divided into six items. The second, third and fourth item relate to the literature review and the theoretical framework. This is where we excel in higher education and the humanisation processes of society, multiple intelligences are explored in the co-creation of humanity and the humanisation of higher education for the world of business. In the fifth item, we realise the empirical study, whereas the sixth presents a general discussion and the final remarks, which precedes the presentation of the references.

\section{Higher education in the humanisation of society}

Teaching is an exciting, complex and demanding profession. Its success depends on multiple variables and the combination of professional, personal and social skills (Orts, 2011). In his professional dynamics, in addition to the knowledge of the scientific area, a good teacher should enshrine knowledge of pedagogy, sociology and daily life, to entangle his attitudes, behaviours, along with ethical-moral and social-environmental commitments. This is the material the teacher resorts to help the building of more human, healthier and more committed relationships to society. As Orts (2011) considers the teacher contributes to a more just, more peaceful and supportive society in line with this perspective. He/she unveils his/her emotional competence to students because an emotionally competent teacher knows and lives the universal values of life. However, the success of teaching-learning is not in doing more, but in doing differently (Orts, 2011). This perspective values the qualitative aspect differently. In light of this, the person must be insightful in the way of seeing, acting and behaving in order to know how to discern teaching for life, because discerning is to perceive, accept, understand, evolve and love unconditionally (Portela, 2018), both from the vertical and the horizontal point of view. Notwithstanding, discernment rests on wisdom to know how to "stop", in order to think, internalise, see, meditate, reflect, act, listen, give an opinion and elucidate. Therefore, knowing how to stop is a gift from the universe that is available to all citizens and it is fundamental to the success of learning.

In their orthodox (traditional) learning process, young people learn a lot in isolation and, at the end of this process, there may be a sum of disconnected learning. Despite the importance of these learnings, because they are an integral part of multiple intelligences, learning still needs to make sense and interconnect them to allow the student to develop his/her various cognitive, affective, affective, relational and social domains. As society is deficient in social and moral balances, will the values of materiality, and very focused on the financial aspect, make the student a good professional in the 
business area and a good citizen? His/her learning process embodies other dimensions of equal importance that are often ignored and that make it difficult to improve the student's social quality of life. In this manner, the teacher and the system also fail because they focus more on the increases in individual financial savings and less on the importance of the student's ethical and social heritage. To train holistically, it seems relevant to us to involve the student in community activities, to stimulate his/her ability to know how to accept and respect without judging differences and to assume a more open attitude to understand and cooperate with the "other". These characteristics are an integral part of the student's development because they help to blur the teaching individualistic and materialistic orientations, which are adverse features to the construction of a more balanced society. These foster the greed that grows and imprisons the person amputates freedom and shortens happiness. Tin this line of thought, Ghoshal (2005: 88) states: "I believe that as academics, we may have been guilty of overexploiting our freedom". In addition, the opportunistic behaviour of the human being tends to wax imperfections and social costs (Ghoshal: 2005). They tend to wane fraternal feelings and positive human emotions to resort to a more calculating and deterministic treatment, which dehumanises society. Therefore, it is necessary that human thought gravitates around the world and social organisation because it is time to show our responsibility if we believe that our work is relevant to the world (Hambrick, 1994).

In addition to venerating materiality, present-day society also "fails" when it does not underlines virtues. Therefore, Giacalone (2004) considers that education should be structured in line with five main objectives (i) empathy, (ii) generativity; (iii) mutuality, (iv) civil aspiration, (v) intolerance of ineffective humanity, because he understands that these are essential values for building a more intuitive/noncognitive world. To this end, the school needs to devise another geopolitical organisation that works the inputs of cooperation, ethical commitments and awareness, while observing ecological, social and cultural criteria (Paymal, 2016). Such guidance leads the citizen to a more ecocentric, less self-centred society and more guided by the forces of the heart. As a result, tomorrow's schools should call themselves: "comprehensive school for the third millennium, educational community, bio-school, parallel school, alternative school, wisdom centre, integral development centre, schoolhouse, the school with a conscience" (Paymal, 2016: 233). As any system depends on the correlation of ecosystem forces, ignoring the social side of the human aspect is amputating the results of public policies because the teaching of business should be an open, interdependent and (co)responsible system for the good of citizens and for their quality of life. This is a path so the teaching of business embodies characteristics that help humanising society, which contributes to the economic and social balance and favours the economic activity within the real world (Maréchal, 2001). 


\section{Multiple Intelligences: an avenue for the co-creation of humanity}

Multiple intelligences, as designated by Gardner $(1995 ; 1999)$, are at the basis of potential human development. Each individual may have different levels of development of their abilities and skills because they focus on specific aspects of that multiplicity of intelligence. In this regard, we wonder about the performance of teaching for the holistic development of the individual. According to Gardner (1995; 1999) and Pereira and Costa (2017a; 2017b), teaching is liberating and co-creating provided it respects multiple intelligences. This approach has opened windows to the discussion of different bits of intelligence in the individuals' global development. Paymal (2016) refreshes such bits of intelligence and presents the following set:

Table 1: Typification and nature of multiple types of intelligence

\begin{tabular}{lll}
\hline$N^{\mathbf{o}}$ & Types of Intelligence & Nature \\
\hline 1 & Linguistic or verbal & Cognitive \\
2 & Logical-mathematical & Cognitive \\
3 & Spacial & Spacial, artistic and aesthetic \\
4 & Body-Kinesthetic & Body \\
5 & Musical & Musical \\
6 & Interpersonal & Psychological, social, educational and multicultural \\
7 & Intrapersonal & Psychological and aesthetic \\
8 & Naturalistic & Ecological \\
9 & Transcendent or Spiritual & Spiritual \\
10 & Intuitive or Energetic & Psychic \\
11 & Emotional & Emotional \\
12 & Practical & Practical and productive \\
13 & Co-creative & Multifaceted (heterogeneous) \\
\hline
\end{tabular}

Source: Paymal (2016: 138/9)

In addition to that typology of intelligence, literature indicates many others, such as digital intelligence, lateral intelligence, associative intelligence, love intelligence (or affective intelligence, or conciliatory intelligence), multidimensional intelligence or cosmic intelligence, humorous intelligence, planning intelligence, sexual intelligence, survival intelligence, emergency intelligence, ludic intelligence, collective intelligence (Paymal, 2016: 140). Thence, in view of the richness of multiple intelligences, we could ask, overall, what are the intelligences which, for each individual and in each situation, have greater relevance? How can the teaching process respond to this diversity of skills? Although these seem to be simple questions, they are actually difficult to answer. However, in view of this reality, in order to co-create a school that contemplates that diversity, it is indispensable to meet some levels, according to the various bits of intelligence, of which Paymal (2016) suggests: 
(a) dream and design a school for the community that is everyone's, for all and inclusive;

(b) prepare emotionally stable individuals;

(c) prepare individuals to know each other, to listen, to participate and perform activities together;

(d) define educational processes and explore pedagogical tools;

(e) establish networks and accept/embody the local reality.

Paymal's perspective is in line with a teaching process which embodies humanising characteristics. Nevertheless, in Giacalone's opinion (2004), the teaching process is not yet focused on transcendence (transcendental or spiritual intelligence). Indeed, it is is not statistically measurable and it does not stem from a process with linear results either. In addition, it seems to be an obstacle to the holistic development of the individual and the humanisation of society, with a direct influence on business and its management.

\section{How to humanise higher education for the business world?}

According to Pfeffer and Fong (2002), business education has become an opportunity that has flourished over the past few decades, given the employability that such courses outshine as it is the case of the Masters in Business Administration (MBA's). Notwithstanding their attractiveness, these courses have been criticised for failing in preparing leaders for the real world of work and for not giving sufficient emphasis on the business ethics-related issues (Pfeffer and Fong, 2002; Bennis and O'Toole, 2005). Business courses (MBAs) have proliferated with very diverse typologies, such as late afternoon courses, evening courses, weekend courses, part-time courses, inter alia (Pfeffer and Fong, 2002). According to Rubin \& Dierdorff (2009), students and stakeholders have also criticised these courses due to the gap between the skills taught and those that should actually be taught. In this regard, Bennis and O'Toole (2005) and Eberhardt et al. (1997) claim that business schools have lost track of their mission because their programmes should be more relevant to the real market. According to Bennis and O'Toole (2005), Ireland (2015) and DeNisi and Pettigrew (2012), another strand linked to failures of the programmes in the preparation of individuals in the art of doing business, is the obligation imposed on university professors for publishing their research in indexed journals. In the opinion of these authors, by emphasising scientific research in the academic activity, business schools are contributing to devaluing their most humanising, social and cross-cutting contents. This sort of behaviour conditions the full development of the student and hinders their future integration into the labour market due to the skills gap, particularly at the intrapersonal and interpersonal level (Krstić, 2012; 2014; Krstić and Krstić, 2016). 
In this regard, Bennis and O'Toole (2005) also pinpoint the implications of the teachers' dedication to research to the detriment of their dedication to students. They say that these professor-researchers can be extraordinary as scientists, but that this does not guarantee their pedagogical skills and that sometimes contributes to their discomfort in the classroom context. Bennis and O'Toole (2005) also say that one of the problems of business schools is that they use $95 \%$ of the contact time with students with technical skills and the remaining $5 \%$ with transferable skills. These ratios are indeed insightful, as they elucidate that MBA's do still fail to navigate the waters of multiple calibrated bits of intelligence. However, we recognise that in university education there have been efforts to integrate into the curricular plans other kinds of skills, the so-called soft skills, in order to balance the development of the student's skills/competencies.

MBA's must respond to real needs and prepare the student to perform the job. They should prepare the individual for organisational and social performance, without ignoring that the student is a living element of society. Therefore, according to Paymal (2016), to be faithful to their mission, MBA's and all teaching should allow students to be able to build their life project in line with the dynamics of society. It should also contemplate intrapersonal development so that the student can build his/her emotional, physical and spiritual balance because these are values that embody his relational balance. In this process, teaching should provide the basis for an autonomous, creative, researching and rich relationships, to make the student an element of change. Moreover, the school must work to enhance the student's self-esteem and help him/her be able to value, accept and respect his/her inner world. Similarly, respecting the others and the environment is the structural guidance to reverse the deficit cycle of democracy and of respect that takes place in society. At the same time, the school should lead the student to participate voluntarily in the community and to be an active and constructive citizen. Thus, preparing the student for ethical challenges in business and for the full respect of the different elements belonging to the network of contacts where the business is developed becomes a fundamental nexus in the training of the student.

In a humanised society "the human being feels the deep pleasure of synchronous vibration with nature" (Portela, 2018: 21). Therefore, in this humanised process, injustice is assumed as a social disease one should strive to heal. Moreover, citizens are more sensitive to see in hunger, misery, disrespect, humiliation and life without worthy conditions as being characteristics of the futility of matter that unveils flaws and deficits of societal, personal and relational development. A more humanised society practices and promotes social responsibility, which companies must cherish and develop to contribute to a more inclusive society and, thereby, gain competitive advantage. A more humanised society is more committed to things, people, nature and addresses citizens with respect and dignity. It cares about 
everything and everyone. It gives importance to the quality of life in the workplace and respects the freedom of each citizen. It aims to mitigate differences and inequalities and seeks to enhance environmental, economic, social and human respect. This more humanised look at society and production institutions leads us to underline the need to adjust the curricular plans of the courses, in particular those related to business, by endowing them with human and social values that integrate the students in a more friendly society to all and everything else that exists in the universe.

\section{Empirical Study}

\subsection{Methodology}

The empirical study that we developed in this investigation is the result of the analysis of two debate groups with in-depth discussion and subsequent content analysis. We have resorted to the use of the Focus Group methodology. In this study, we understand Focus Group as a discussion among specialised individuals. The individuals belonging to the focus group are guided by seeking to innovate in their pedagogical practices aimed at the business area, seeking to link the theoretical orientations of the higher education courses with the current practices of business management in the search for processes aimed at humanising the relationships of business practices. This is an instrument of the qualitative methodology that resorts to small groups and should be moderated by one or more facilitators (Guerra, 2006). In this research, two Focus groups were held and moderated by two facilitators.

We have realised a lengthy in-depth discussion on what companies expect from business teaching and what is the university actually offering. In this sense, the main questions under analysis were (i) What perception do companies have about the business teaching-learning model? (ii) What kind of training should business schools provide students with? (iii) Should the training plan include the teaching of values? (iv) What is the role of the university in humanising business education? (v) Can leadership be taught? (vi) And what kind of leadership?

\subsection{Content Analysis}

Using Bardin's methodology (1997), we pre-analysed the various meanings resulting from the frequency of expressions. The outcome of this analysis was the nine categories of contents:

(i) Characteristics of the university business education offer 
For focus group participants, the great challenge posed to the university and, specifically to business schools, is to discuss the advantages of reconciling academic education objectives with business objectives. In this way, the University seeks to offer courses in the business area that are in line with the needs of companies and thus try to respond competitively to the demands of the labour market. However, this offer should bring together the skills that are considered fundamental and which should be embodied in the teaching-learning process throughout the course, especially autonomy and leadership.

(ii) Skills students should hold

All participants recognise that universities currently value research-related tasks more than the pedagogical ones. This practice has raised several difficulties in innovating the curriculum and introducing changes in the teaching-learning process, particularly in terms of the introduction of humanisation values, both in the programmatic contents and in the learning processes. However, it seems to raise consensus that, in addition to the scientific and technical skills of each curricular unit, the business school should promote the transversality of knowledge. In this light, the school should actually enhance interdisciplinarity procedures and the development of autonomy and group work skills. These will enable them to develop leadership and decision-making skills. However, insofar the teaching of business is concerned, companies seem to value more technical skills and the learning of the management tools needed for businesses. In the discussion, it was also mentioned the importance of the students' competence to know how to interact and develop work for the community. However, some participants reported that a high number of students per class has made such an objective difficult to achieve. In this regard, teaching should be monitored and personalised. Only in this way, according to the participants, teaching could be closer to the processes of humanisation and thus foster greater interaction with the community. Such cooperation would only be possible in classrooms of smaller size which would strengthen the University's relations with the business community.

(iii) Development of student social awareness.

In general, the social awareness of university students has been developed, in a case-by-case basis, through volunteer actions in their communities of origin and in the classroom by means of their participation in discussions on economic sustainability often due to environmental reasons. However, the student's daily life seems to be less tied to life in the community of the geographical area where they study and more linked to their student community. According to one of the participants of the focus group the student's social awareness is quite slim and states: "the feeling I have is that the student has no interaction with the local community. Basically, they stay in the university surroundings and this is 
from where they go home over the weekend... and this is from where they go to other urban centres when they go to an internship or when they get a job...". Nonetheless, one of the participants raised the following question: "will it be a priority for companies that the student learns at the university to raise his/her social awareness? If so, how could this learning process be developed in the interests of the companies?"

(iv) Teaching-learning of values and leadership

With regard to the teaching of values at the university, the issue generated controversy and it is the opinion of some participants that society should play this role and not the university. According to one participant: "for me, teaching values is a problem. I think that role should be played by society. Moreover, society should be attentive to the needs of its citizens, teaching them and raising awareness of cooperation and sharing". In this sense, according to the participants, it is essentially up to society and less to the university, the concern to train good citizens. In this way, there would be a concern to establish a unique relationship between each citizen to the community. Whilst reinforcing this idea, another participant said: "in the classroom, I am afraid to teach values and all that entails. Students, when they get admission to the university are eighteen or older, do already have standards of behaviour. In this way, I am always very afraid to teach behavioural norms because teaching values have, for me, complex paths...". Another participant opened the discussion and said that, in the classroom, another order of values should be transmitted to students such as "rigour" and respect for norms, exemplifying with the fulfilment of academic activities. Another participant complemented this idea by focusing on the importance of ethical values: "teaching ethics is to reinforce its importance and signals the value that is attributed to these domains". In addition to values, and what is important to teach, both for companies and students, we addressed the students' perception on which skills seem to be important to acquire to enhance their edge in the labour market. Some participants mentioned leadership and that learning to be a leader seems to be a very important value for students. Nevertheless, on the other hand, can learning leadership be isolated from other social skills? Can a leader not care about the conditions for the success of his/her company? After all, are companies looking for leaders or bosses?

(v) The role of the university in bringing the student closer to society.

Should the university have a role in the process of bringing the student closer to society? How could the teaching-learning model incorporate this approach? For some participants, society should play this role and not the university, since it is essentially society that should prepare good citizens. It is worth mentioning that a participant in the focus group, despite considering that learning citizenship values 
should be up to society, he considers that there is a role of bringing the student closer to society that arises from both society and university. As far as the role of the university is concerned, he says "there is a part which entails the awareness that there is a world out there and that we have to worry about this world because we live in it. The other part is the better the world the better it will be for everyone, including university performance. This seems to be an incentive that will lead the student to look at and behold the world around him/her." On the other hand, this role will also be up to society, as well as to develop efforts to facilitate the integration of students into society and to facilitate their access to university. The same participant adds "I think it is an important role... I no longer have so many present cases of integration success...; however, there was clear municipal support to this, with incentives to house rental for students to settle in the city centre. In fact, institutions are mainly outside the centres, especially when cities grow, as it is the case of Braga. Hence, policies with the objective of attracting and co-opting graduates - to fix human capital after the completion of graduation - is relevant, and the role of the municipality is very important in the process. In order to create these contexts of interaction with the local community, living in the city centre means taking half an hour on foot to the university campus. This relies on the premise that there exists transportation from the city centre to the campus, ..." However, this would only be the creation of integration facilities; nonetheless, it should be essentially up to the students to participate in their community integration process. In this regard, another participant adds "but in this case, it is not the students who decide something like this? This is not an individual decision, but local politics! These things arise from the initiative of the higher hierarchy, such as the Mayor, the municipality and the local government politicians that manage the City Hall. I do not think this has anything to do with the student's social awareness, although I understand this interaction would be fruitful." However, the participant enriched his reflection by self-questioning the importance given to the city culture, the students' social awareness and their lack of sensitivity to the problems of the city and added "I once asked students if they have ever been to the theatre or if they have ever participated in cultural programmes offered by the city. This process would be a way to link the university to the cultural portfolio of the city. For example, the welcoming session to the students at the beginning of the academic year which includes visits to museums free of charge. These activities draw the students' attention to the city. On the other hand, if students do not go downtown, they are not aware of the homeless sleeping on the streets and what kind of monuments there are in the city. If we do not stimulate them to know about city life within the framework of a curricular unit, students will not be able to recognise the different aspects of the city."

Why would the enrichment of both cultural and social awareness of the student not also be beneficial within the teaching-learning process in business management? How to look strategically at the role of 
the university? As a matter of fact, "looking" at the city is "looking" at the whole where universities, institutions and companies have connecting roles indispensable to a convergent and sustainable socioeconomic development.

(vi) Training through the lenses of leadership

For many participants, leadership is a cornerstone in the business area and it is associated with the issue of being entrepreneurial and the value of entrepreneurship in the process of the teaching-learning economy and business management. One of the participants stressed that "we are everywhere with this value of leadership and that it seems important to me, in such a way that it appears in various aspects of the teaching process." However, another participant claimed that being a leader is nothing more than perception and stated that "to what extent does what we convey lead the students to think that the important thing is to be a leader?" This participant invoked another competence which he considers more important and which consists of knowing how to work as a team at least as much as to be a leader. He wonders "if one is a good element of the team, will this not be as important as being a leader?" Another participant thinks this is probably also another leadership indicator. However, he also states that students are formatted in the role of leadership for good professional performance. As such, they would like the courses to develop leadership skills because they believe that this competence is highly valued in the labour market." However, he wonders "Is really the leadership capacity the most valued in the labour market? It seems to me that for the labour market is not always that most valued capacity; however, students think it is." Finally, another participant said that despite the importance of transversal skills, the most evident value of the student curriculum for a company is its final quantitative score (classification) and that only, exceptionally, includes other parameters in the student's assessment. In this context, we wonder if there is once again no conflict between the meanings of leadership and manager because the values of both are different.

(vii) Training for autonomy

Although teaching is still centred on technical knowledge, non-technical and transversal skills gradually emerge with increased importance. These competencies embody values that foster and enhance the autonomy which teaching-learning should promote in university education, as it is the case with business teaching. Some participants question "if academic business education exhausts itself in the type of technical and vocational training, will the students lose other equally important skills that are part of the university teaching-learning objectives?" As autonomy is an important competency to be taught at the university and that will produce positive externalities on the companies, one participant reinforced this idea by saying that students "should be independent and know how to submit valid and consistent 
proposals such as knowing how to argue and be autonomous." However, another participant considered that there should be a balance between the needs of companies on what should be taught in universities and the objectives of academic-university education. Thence, it seems that autonomy is a strategic value for both the company and the university and it should be developed at the university and subsequently within the companies. At deferred moments, positive external effects will arise within companies and will be reflected in the university organisational models thereby improving new forms of autonomy development.

(viii) Characteristics of the demand for university education by companies: technical training, computer science and entrepreneurship

Notwithstanding the fact that many employers consider universities and that university education should promote student approach to society, on the other hand, they also understand that useful study plans for the companies should be more focused on technical curricula, on management instruments, entrepreneurship teaching and software instruments used in companies. Nevertheless, according to focus group participants, such purposes seem difficult to reconcile and to operationalise. One of the participants reinforced the idea by saying that many companies bring their training needs to the university, saying that "it is up to the university to bring students closer to society, teaching what is important to companies and to meet the needs of the labour market." However, this participant expresses disagreement about a teaching mode only directed at the needs of companies, justifying " I do not think it should fit the university, or a university course, to teach someone to work on specific tasks of each company. One thing is to develop skills, where one can include the social awareness that can be included in specific curricular units. Another thing, however, is to make a university approach to society the way employers suggest". Other participants have the perception that for companies the meeting of university education with society is limited to more technical than social concerns.

Under these circumstances, if on the one hand business training should involve the needs of companies and business processes, on the other, training for the companies is more comprehensive and cut-crosses the development of technical and instrumental areas with the scientific innovation/development which the corporate reality entails. This development, in turn, can lead to improvements in instrumental skills, with very significant positive effects on the level of the individual's performance within the company.

(ix) University responses to the needs of companies: generating skills

The response that business schools seek to give to the needs of companies has raised some controversy and disagreement among participants. For some, the university would find itself more dedicated to knowledge than for its connection to society. In this respect, the contribution of scientific research would 
be more important in the student learning training process than the development of social inclusion issues. Despite some objections, however, they consider that business schools have responded to these needs through training programmes called "generating skills" with more technical, professional and social statements. In this respect, sessions have been implemented aimed at students who promote the development of transversal skills and who have allowed students to meet with company managers, with community representatives in various areas of cultural and social performance and also with profit and non-profit institutions.

Synthesising the above-mentioned contents, as summarised in figure 1 below, we note that a curriculum aimed at humanising business education, in addition to conventional technical skills, should also cover other skills than the student's approach to society, namely autonomy, student social awareness, leadership, entrepreneurial capacity, inter alia.

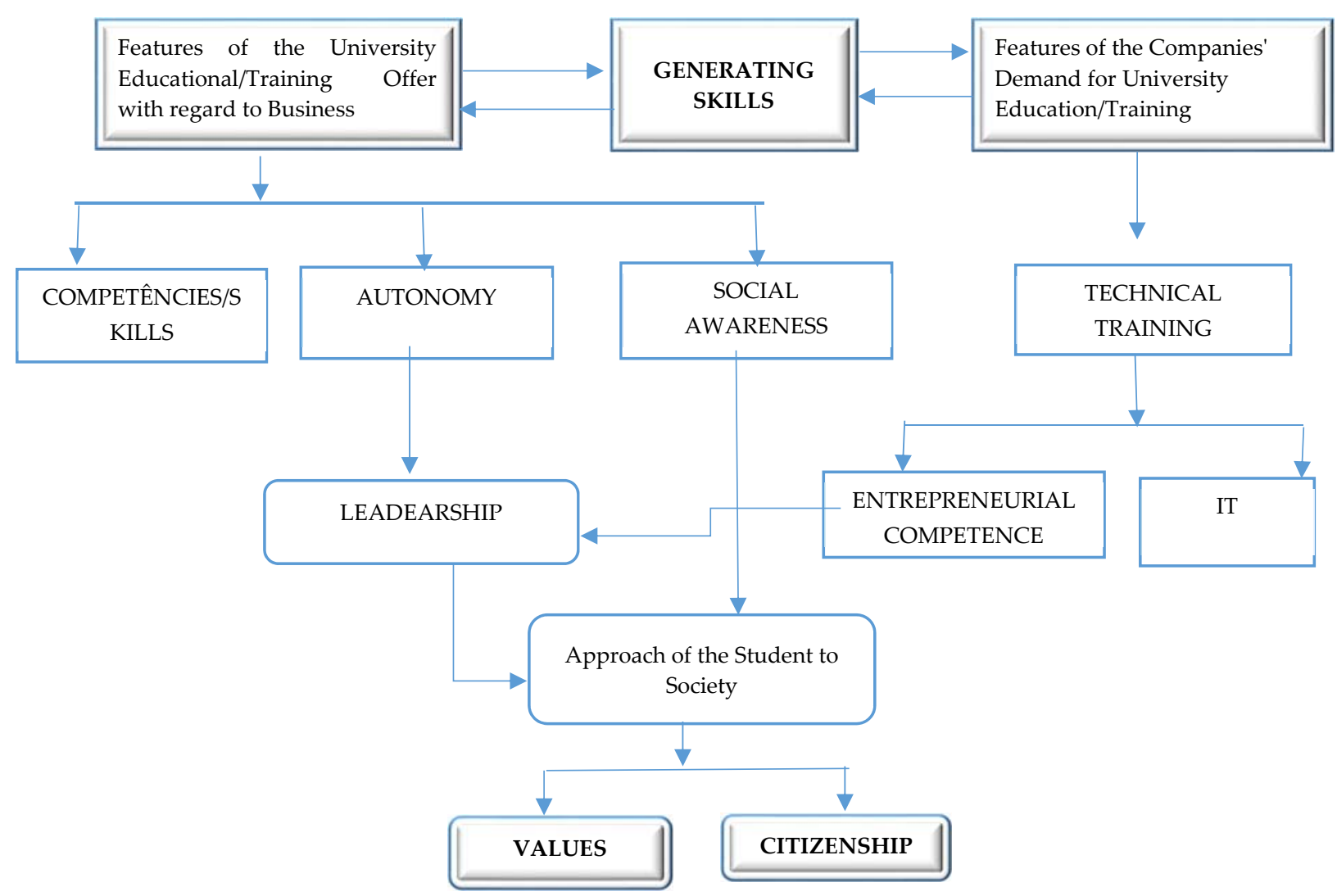

Figure 1. Content association diagram

Source: Authors' model 


\section{Discussion and Closing Comments}

Business management involves feelings. These lead to greater efficiency in emotion management, in addition to traditional management of companies, respectively: assets, financial, logistical, commercial, human resources and social responsibility. Nonetheless, the management of a company is complex and involves a network of internal and external, intrapersonal and interpersonal relationships. Also, the objectives of stakeholders and shareholders are not always in line with this complexity, since, in the present societal context, maximising economic value requires a convergence of all the elements contributing to the production of economic value. Among these objectives, the satisfaction of the worker, both at work and in the family, is gaining prominence. His/her freedom of expression and access to information allows him/her to perform better, both individually and as a team, and an environment of creativity materialises and that is associated with his/her degree of internal freedom. This reality presupposes that university education in the business area must correspond to the interests of companies and workers, in a system in permanent transformation. However, in view of the results of our research, there is indeed a strong disparity between the interests of university practices, the requirements that companies expect from universities and the university organisational model in force. This model does not very often respond to the business world that is in great technological transformation. This metamorphosis should not isolate the company from its employees or employees from society. The paths to walk through to adjust that reality is not easy and they are still a challenge for both universities and companies. Hence, one may understand the feelings of insecurity presented by the professors participating in this research and the ambiguity of purposes expressed both by teachers and the training requirements requested by companies to the university. Therefore, we believe that this whole process of humanisation, in teaching, in companies and in society in general, implies a permanent dialogue between all participants, seeking a convergence of action in the university and in the company, with a view to the co-creation of humanisation. This objective does not seem to be contradictory to the competitive environment of companies and university education, but it is rather an important tool for its dynamism because it can foster cooperation without trampling competitiveness objectives, which underlines that ethical behaviour is the foundation for building the responsible competitive world. Therefore, ethics should be present in all business teaching-learning processes. Its importance outshines at deferred times, when the student assumes responsible conduct, both in his/her workplace and in the community.

The value of leadership must be a reference value, both in business teaching and the demands of the labour market. However, leadership is not synonymous with leadership, as leadership promotes freedom, cooperation, empathy, responsibility, values that are strategic for corporate creativity. 
Leadership does not imply that the employee assumes a traditional and hierarchical role in the organisation. All employees have such a role in the current context of the organisational and social transformation. Even silently, not being a "leader", an employee may have a leading role in his organisation and be more productive for the company. Therefore, the paths of leadership should not be subordinate to the criterion of "obedience", because obedience does not promote creativity and prevents the search for novel solutions to face new challenges. Is this not the most important value to strive for competitiveness?

The training of a student is the responsibility of everyone - family, social relations, support institutions, society, universities and companies. Therefore, the teaching model for business cannot be exhausted in a set of disciplines focused on technical and instrumental training. This aspect must integrate emotional, relational and spiritual variables to form a balance in the students' education, leading them to contribute to improving the performance of companies, society and their relationships. These competencies are the distinctive additive in competitiveness and enable performance gains with positive impacts on the company and the employee, stakeholders and society in general. In this way, one should not isolate each of these variables, but to stimulate their interaction and synergies because they are part of a whole. For this reason, business education should include these guidelines because they humanise society and render companies aware of citizenship behaviours, as it does about students. Thence, we understand that training "good citizens" is not only the responsibility of society but also of educational institutions, as it is the case with higher education for business.

\section{References}

Bennis, W., \& O'Toole, J. (2005). How Business Schools lost their way. Harvard Business Review. Available at https://hbr.org/2005/05/how-business-schools-lost-their-way, consulted in 22-022019, pp. 96-104.

Bardin L. (1977). L'analyse de Contenu. Presses universitaires. France.

DeNisi, A., \& Pettigrew, A. (2012). The present and future of the business school professional: Understanding the changing rules of the game. Unpublished proposal submitted to the Academy of Management, Briarcliff Manor, NY.

Eberhardt, B., Moser, S., \& McGee, P. (1997). Business Concerns regarding MBA Education: effects on recruiting. Journal of Education for Business, 72(5), 293-296.

Gardner, H. (1995). Inteligências Múltiplas: a teoria na prática. Tradução de. Maria Adriana Veríssimo Veronese. Porto Alegre: Artes Médicas.

Gardner, H. (1999). Intelligence reframed: Multiple intelligences for the 21st century. New York, NY: Basic Books. 
Ghoshal, S. (2005). Bad Management Theories are Destroying Good Management Practices. Academy of Management Learning \& Education. 4(1), 75-91.

Giacalone, R. (2004). A Transcendent Business Education for the 21 ${ }^{\text {st }}$ Century. Academy of Management Learning \& Education, 3(4), 415-420.

Hambrick, D. (1994). What if the Academy actually mattered? Academy of Management Review, 19(1), 11-16.

Ireland, R. D. (2015). Our Academy, our Future, Academy of Management Review, 40(2), 151-162.

Khurana, R., \& Snook, S. (2011). Commentary on 'A Scholar's Quest' - Identity Work in Business Schools: From Don Quixote, to Dons and Divas. Journal of Management Inquiry, 20(4), 358-361.

Krstić, M. (2014). Rational choice theory and addiction behaviour. Market-Tržište, 26(2), 163-177.

Krstić, M. (2012). The role of rules in the evolution of the market system: Hayek's concept of evolutionary epistemology. Economic annals, 57(194),123-140.

Krstić, B., \& Krstić, M. (2016). Teorija racionalnog izbora i društvena istraživanja. Sociologija, 58(4), 598611.

Lai, G., Wong, O., \& Feng, X. (2015). Family, School and Access to Social Capital Among High School Students in Urban Nanjing. American Behavioral Scientist, 59(8), 946-960.

Maréchal, J-P. (2001). Humanizar a Economia. Lisboa, Instituto Piaget.

Orts, J. (2011). El professor emocionalmente competente: un puente sobre «aulas» turbulentas. Barcelona, Editorial Graó.

Paymal, N. (2016). La Escuela de los 7 Pétalas. La Paz, Bolívia; Editorial Ox-La-Hun/P3000.

Pereira, O., \& Costa, C. (2017a). The University: An Institution of Co-creation and Social Transformation. Eastern European Business and Economics Journal, 3(3), 245-269.

Pereira, O., \& Costa, C. (2017b). The importance of soft skills in the university academic curriculum: The perceptions of the students in the new society of knowledge. International Journal of Business and Social Research, 7(6),1-12.

Pfeffer, J., \& Fong, C. (2002). The End of Business Schools? Less Success Than Meet of Eye. Academy of Management Learning \& Education, 1(1), 78-95.

Portela, L. (2018). Da Ciência ao Amor - Pelo Esclarecimento Espiritual. Lisboa, Gradiva Publicações, S. A., 5ํㅡㄹ Edição.

Rubin, R., \& Dierdorff, E. (2009). How relevant is the MBA? Assessing the alignment of required curricula and required managerial competencies. Academy of Management Learning \& Education, 8(2), 208-224. 